\title{
THE INFLUENCE OF STRAIN RATE ON THE PLASTICITY OF STEEL SHEETS
}

The paper analyses the influence of strain rate on the behaviour of un-alloyed steels with Re 210-550 MPa in the deformation process. It presents and analyses the results of the influence of the strain rates ranging from $10^{-3}$ to $2.5 .10^{2} \mathrm{~s}^{-1}$ on the yield point, tensile strength, elongation and reduction of area. It analyses the non-homogeneity of development of plastic deformation from both, the macroscopic and microscopic points of view, as well as the influence of the strain rate on the development of plastic deformation. Since the intensity of the influence of the strain rate on the properties of materials depends on their internal structure, the tested steels are divided into three groups based on their yield point and yield point of tensile strength ratio.

\section{Introduction}

The strain rate is an external factor, which significantly influences the limit state of a material, its behaviour in the forming process, as well as on the resulting properties of the formed products $[1,2,3,4,11]$. The influence of strain rate on the strength characteristics (yield point, tensile strength) are described using parametric equations [2, 5, 12]. However, the sensitiveness of a material on the strain rate is a function of the material structure, and it can generally be stated that the "more homogeneous" structure, the higher its sensitiveness to the strain rate $[6,7]$. In general, it applies that increased strain rate results in increased strength characteristics of materials, while the yield point grows more intensively than the tensile strength $[6,13]$. As a result, increased strain rate resulted in an increased of $R_{e} / R_{m}$ ratio, and for certain materials at critical strain rate is ratio $R_{e} / R_{m} \geq 1$, whereas are created conditions of local loss of plastic deformation This fact significantly influences the formability (in particular pressability) of materials as a result of localization of plastic deformation to "suitable" places.

Plastic deformation is characterized by the fact that its development is markedly non-homogeneous. The non-homogeneity degree is a function of internal and external factors. The internal material microstructure (number and structure of phases, grain size, and structure type) is the internal factor. Increased grain size and number of phases result in significantly increased non-homogeneity of plastic deformation. The temperature, the strain rate and the stress state are crucial external factors $[4,8]$.

The influence of the strain rate on the development of plastic deformation should be assessed in terms of the deformed body.
From the macroscopic point of view, an increased strain rate results in an increased non-homogeneity of deformation of the body as a whole. From the microscopic and submicroscopic points of view, the situation is opposite [8]. However, it applies that an increased degree of plastic deformation results in an increased degree of non-homogeneity.

Increasing the strain rate in forming semiproducts or products is one of the ways of intensification of production. Therefore, an attention is paid to the study of the influence of the strain rate on the behaviour of material in the deformation process, but also on the methodology of evaluation of formability at increased strain rates (including impact ones) $[9,10]$.

The sensitivity of materials to the strain rate in the forming process is, as mentioned earlier, a material function, and, therefore, it is useful to analyse this sensitivity especially for new materials intended for cold forming. This is necessary in order to determine the limit state, as well as the properties of the final product. The aim of the paper is to extend the pieces of knowledge and to point out certain problems occurring during forming at increased rates (up to impact loads).

\section{Experimental material and procedure}

Experimental program related to influence of strain rate on plastic characteristics of steel sheets were realized on steel sheets produced by cold forming process. Steel sheets marked as E280G and H340LAD were cold rolled at thickness of $1 \mathrm{~mm}$ and next were hot rolled at the final thickness of $8 \mathrm{~mm}$. Microstructure of tested steels is ferrite-pearlite. From steel sheets were taken samples

\footnotetext{
* Jan Michel, Marian Bursak

Department of Material Science, Faculty of Metallurgy, Technical University of Kosice, Slovakia,

E-mail: marian.bursak@tuke.sk
} 
in rolling direction which were for used for tensile test. The main characteristics of tested steels (carbon content, grain size d, and microalloying elements) are shown in Tab. 1

The basic criteria for assessment of the formability of materials obtained during the tensile test including the yield point $R_{e}$, the tensile strength $R_{m}$, the elongation $\mathrm{A}$, the $R_{e} / R_{m}$ ratio.

The presented test result were obtained on the INSTRON tensile testing machine with the loading rate up to $1000 \mathrm{~mm} / \mathrm{min}$, as well as on an instrumented pendulum impact testing machine with the loading rate of up to approx. $5 \mathrm{~m} / \mathrm{s}$ and on a drop tester By a suitable combination of the loading rate $(v)$ and the deformed length of test bars $\left(L_{0}\right)$, strain rates $\dot{\varepsilon}=v / L_{0}$ ranging between $10^{-4}$ and $10^{3} \mathrm{~s}^{-1}$ could be obtained.

The influence of the strain rate on the development of plastic deformation was observed from the macroscopic and microscopic points of view. The influence of the strain rate on the development of deformation was observed on test bars, whose measured length was divided into $1 \mathrm{~mm}$ divisions. Such prepared test bars were gradually loaded to a certain strain degree (from approx. 5 to $30 \%$ ). After each strain degree, the distance between individual divisions was measured. The test bars were loaded statically $\left(10^{-3} \mathrm{~s}^{-1}\right)$ and dynamically $\left(10^{2} \mathrm{~s}^{-1}\right)$. The mean non-homogeneity was evaluated, $M=\frac{\sum_{1}^{n} U_{x} \cdot m}{n}$ where $\mathrm{n}$ is the number of elements of the statistic population. The other quantities result from Fig. 8 . For evaluation of micro non-homogeneity of plastic deformation, a similar procedure as for evaluation of macro non-homogeneity was used. A metallographic sample was prepared on the test bar stem, and a grid with the mesh size of $0.05 \times 0.05 \mathrm{~mm}$ was created using a microhardness tester in the area of $1 \times 0.5 \mathrm{~mm}$. The mean strain $\varepsilon$ was measured on the length of $1 \mathrm{~mm}$, and also on each division at individual strain degrees from 5 to $35 \%$.

\section{Influence of the strain rate on the basic mechanical properties}

The influence of the strain rate on the basic mechanical properties of the tested steel $\mathrm{C} 4$ is shown in Fig. 1, which indicates that increased strain rate results in increased strength properties, while the intensity of growth of $R_{e}$ is higher than that of $R_{m}$. The dependence of the strength properties on the strain rate for unalloyed high-grade steels in the interval from $10^{-3}$ to $10^{3} \mathrm{~s}^{-1}$ was described using parametric equations (1), (2), mostly in the shape presented in $[2,5,7]$,

$$
\begin{aligned}
& R_{e \dot{\varepsilon}}=R_{e \dot{\varepsilon}_{0}}+A \cdot \ln \left(\dot{\varepsilon} / \dot{\varepsilon}_{0}\right) \\
& R_{m \dot{\varepsilon}}=R_{m \dot{\varepsilon}_{0}}+B \cdot \ln \left(\dot{\varepsilon} / \dot{\varepsilon}_{0}\right)
\end{aligned}
$$

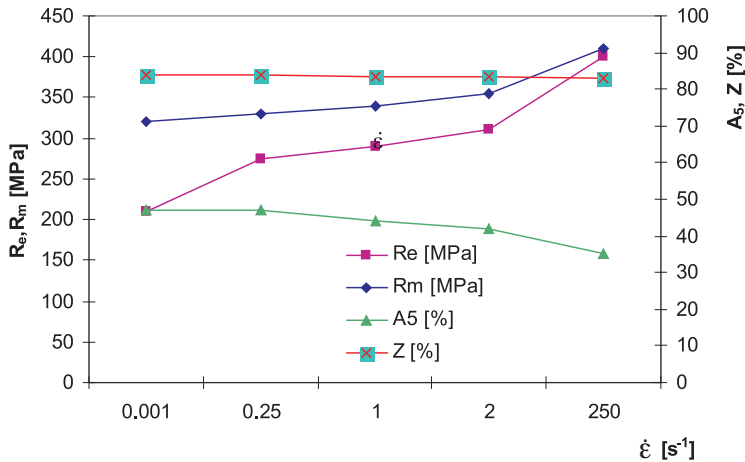

Fig. 1 Influence of the strain rate $\dot{\varepsilon}$ on mechanical properties of steel $\mathrm{C} 4$

where $R_{e}, R_{m}$ are the yield point and the tensile strength at the respective strain rate $\dot{\varepsilon}$, and $R_{e \dot{\varepsilon}_{0}}, R_{m \dot{\varepsilon}_{0}}$ are the yield point and the tensile strength at the static strain rate $\left(10^{-3} \mathrm{~s}^{-1}\right)$. The A and B parameters are material constants characterizing the sensitivity of the material to the strain rate. Fig. 2 shows the influence of the strain rate on the increment of the yield point $\Delta R_{e}$ of steel C33 after various heat treatments. The as-quenched steel has the lowest sensitivity to $\dot{\varepsilon}$, because the martensitic structure has the greatest number of obstructions to dislocation movement, and the as-nor-

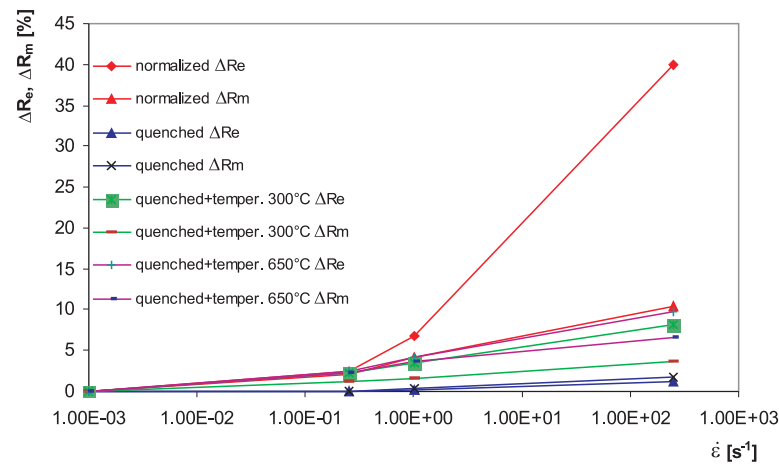

Fig. 2 Influence of the strain rate $\dot{\varepsilon}$ on the increment of strength properties $\Delta R_{e}$, or $\Delta R_{m}$, after heat treatment, compared with the initial state $\left(\dot{\varepsilon}=10^{-3} s^{-1}\right)$ of steel C33, after various heat treatments

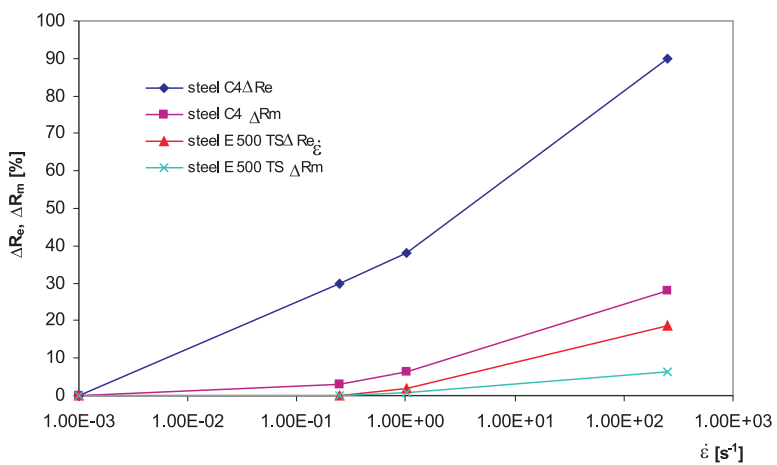

Fig. 3 Influence of the strain rate $\dot{\varepsilon}$ on the increment of strength properties $\Delta R_{e}$, or $\Delta R_{m}$, compared with the initial state at $\dot{\varepsilon}=10^{-3} s^{-1}$ for various steel grades. 
Mechanical properties of tested steels at characteristic strain rates.

Table 1.

\begin{tabular}{|c|c|c|c|c|c|}
\hline \multirow{2}{*}{ Tested steel } & \multirow{2}{*}{ Characteristics } & \multicolumn{4}{|c|}{$\dot{\varepsilon} \mathrm{s}^{-1}$} \\
\hline & & $10^{-3}$ & $2.5 \cdot 10^{-1}$ & 1 & $2.5 \cdot 10^{2}$ \\
\hline $\begin{array}{c}\mathrm{C} 4 \\
\mathrm{C}<0.04 \% \\
\mathrm{~d}=0.031 \mathrm{~mm}\end{array}$ & $\begin{array}{c}R_{e}[\mathrm{MPa}] \\
R_{e} / R_{m} \\
A_{5} \quad[\%]\end{array}$ & $\begin{array}{c}210 \\
0.65 \\
47\end{array}$ & $\begin{array}{c}275 \\
0.8 \\
46\end{array}$ & $\begin{array}{c}290 \\
0.83 \\
44\end{array}$ & $\begin{array}{c}400 \\
0.93 \\
35\end{array}$ \\
\hline $\begin{array}{c}\text { E280G } \\
C<0.04 \% \\
d=0.009 \mathrm{~mm}\end{array}$ & $\begin{array}{c}R_{e}[\mathrm{MPa}] \\
R_{e} / R_{m} \\
A_{5} \quad[\%]\end{array}$ & $\begin{array}{c}295 \\
0.70 \\
30\end{array}$ & $\begin{array}{c}340 \\
0.79 \\
27\end{array}$ & $\begin{array}{c}350 \\
0.80 \\
25\end{array}$ & $\begin{array}{c}459 \\
0.9 \\
22\end{array}$ \\
\hline $\begin{array}{c}\text { H340LAD } \\
\mathrm{Nb}, \mathrm{V}<0.1 \% \\
\mathrm{~d}=0.008 \mathrm{~mm}\end{array}$ & $\begin{array}{c}R_{e}[\mathrm{MPa}] \\
R_{e} / R_{m} \\
A_{5} \quad[\%]\end{array}$ & $\begin{array}{c}350 \\
0.81 \\
26\end{array}$ & $\begin{array}{c}380 \\
0.79 \\
26\end{array}$ & $\begin{array}{c}430 \\
0.82 \\
26\end{array}$ & $\begin{array}{c}540 \\
0.94 \\
24\end{array}$ \\
\hline $\begin{array}{c}\mathrm{C} 10 \\
\mathrm{C}<0.10 \% \\
\mathrm{~d}=0.022 \mathrm{~mm}\end{array}$ & $\begin{array}{c}R_{e}[\mathrm{MPa}] \\
R_{e} / R_{m} \\
A_{5} \quad[\%]\end{array}$ & $\begin{array}{c}280 \\
0.63 \\
41\end{array}$ & $\begin{array}{c}340 \\
0.74 \\
40\end{array}$ & $\begin{array}{c}360 \\
0.78 \\
40\end{array}$ & $\begin{array}{c}490 \\
0.94 \\
40\end{array}$ \\
\hline $\begin{array}{c}\mathrm{C} 28 \\
\mathrm{C}<0.28 \% \\
\mathrm{~d}=0.015 \mathrm{~mm}\end{array}$ & $\begin{array}{c}R_{e}[\mathrm{MPa}] \\
R_{e} / R_{m} \\
A_{5} \quad[\%] \\
\end{array}$ & $\begin{array}{c}370 \\
0.68 \\
30\end{array}$ & $\begin{array}{c}410 \\
0.74 \\
30\end{array}$ & $\begin{array}{c}420 \\
0.75 \\
31\end{array}$ & $\begin{array}{c}540 \\
0.90 \\
33\end{array}$ \\
\hline $\begin{array}{c}\mathrm{C} 33 \\
\mathrm{C}<0.33 \% \\
\mathrm{~d}=0.012 \mathrm{~mm}\end{array}$ & $\begin{array}{c}R_{e}[\mathrm{MPa}] \\
R_{e} / R_{m} \\
A_{5} \quad[\%]\end{array}$ & $\begin{array}{c}440 \\
0.62 \\
27\end{array}$ & $\begin{array}{c}451 \\
0.62 \\
26\end{array}$ & $\begin{array}{c}470 \\
0.63 \\
26\end{array}$ & $\begin{array}{c}630 \\
0.80 \\
27\end{array}$ \\
\hline $\begin{array}{c}\text { C33 } \\
\text { quenched }\end{array}$ & $\begin{array}{c}R_{e}[\mathrm{MPa}] \\
R_{e} / R_{m}\end{array}$ & $\begin{array}{l}1910 \\
0.81\end{array}$ & $\begin{array}{l}1910 \\
0.81\end{array}$ & $\begin{array}{l}1910 \\
0.83\end{array}$ & $\begin{array}{l}1935 \\
0.81\end{array}$ \\
\hline $\begin{array}{l}\text { C33 quenched } \\
\text { +temp. } 300^{\circ} \mathrm{C}\end{array}$ & $\begin{array}{c}R_{e}[\mathrm{MPa}] \\
R_{e} / R_{m} \\
\end{array}$ & $\begin{array}{l}1480 \\
0.92\end{array}$ & $\begin{array}{l}1525 \\
0.95\end{array}$ & $\begin{array}{l}1540 \\
0.95\end{array}$ & $\begin{array}{c}1600 \\
1.0\end{array}$ \\
\hline $\begin{array}{l}\text { C33 quenched } \\
+ \text { temp. } 550^{\circ} \mathrm{C}\end{array}$ & $\begin{array}{c}R_{e}[\mathrm{MPa}] \\
R_{e} / R_{m}\end{array}$ & $\begin{array}{l}820 \\
0.90\end{array}$ & $\begin{array}{l}840 \\
0.90\end{array}$ & $\begin{array}{l}845 \\
0.90\end{array}$ & $\begin{array}{l}900 \\
0.90\end{array}$ \\
\hline $\begin{array}{c}\mathrm{X} 350 \mathrm{M} \\
\mathrm{C}<0.1 \% \mathrm{Nb}, \mathrm{V} \\
\mathrm{d}=0.010 \mathrm{~mm}\end{array}$ & $\begin{array}{c}R_{e}[\mathrm{MPa}] \\
R_{e} / R_{m} \\
A_{5} \quad[\%]\end{array}$ & $\begin{array}{c}380 \\
0.79 \\
34\end{array}$ & $\begin{array}{c}420 \\
0.80 \\
34\end{array}$ & $\begin{array}{c}440 \\
0.83 \\
31\end{array}$ & $\begin{array}{c}590 \\
0.1 \\
30\end{array}$ \\
\hline $\begin{array}{c}\mathrm{X} 420 \mathrm{M} \\
\mathrm{C}<0.1 \% \mathrm{Nb}, \mathrm{V} \\
\mathrm{d}=0.0062 \mathrm{~mm}\end{array}$ & $\begin{array}{c}R_{e}[\mathrm{MPa}] \\
R_{e} / R_{m} \\
A_{5} \quad[\%] \\
\end{array}$ & $\begin{array}{c}430 \\
0.75 \\
30\end{array}$ & $\begin{array}{c}485 \\
0.79 \\
30\end{array}$ & $\begin{array}{c}500 \\
0.8 \\
30\end{array}$ & $\begin{array}{c}610 \\
0.87 \\
30\end{array}$ \\
\hline $\begin{array}{c}\mathrm{X} 500 \mathrm{M} \\
\mathrm{C}<0.1 \% \mathrm{Nb}, \mathrm{V} \\
\mathrm{d}=0.0037 \mathrm{~mm}\end{array}$ & $\begin{array}{c}R_{e}[\mathrm{MPa}] \\
R_{e} / R_{m} \\
A_{5} \quad[\%]\end{array}$ & $\begin{array}{c}550 \\
0.86 \\
28\end{array}$ & $\begin{array}{c}550 \\
0.86 \\
28\end{array}$ & $\begin{array}{c}550 \\
0.86 \\
28\end{array}$ & $\begin{array}{c}640 \\
0.88 \\
28\end{array}$ \\
\hline $\begin{array}{c}\mathrm{X} 560 \mathrm{M} \\
\mathrm{C}<0.11 \% \mathrm{Nb}, \mathrm{V} \\
\mathrm{d}=0.009 \mathrm{~mm}\end{array}$ & $\begin{array}{c}R_{e}[\mathrm{MPa}] \\
R_{e} / R_{m} \\
A_{5} \quad[\%]\end{array}$ & $\begin{array}{c}570 \\
0.87 \\
28\end{array}$ & $\begin{array}{c}570 \\
0.87 \\
28\end{array}$ & $\begin{array}{c}570 \\
0.87 \\
28\end{array}$ & $\begin{array}{c}650 \\
0.89 \\
28\end{array}$ \\
\hline $\begin{array}{c}\mathrm{S} 315 \mathrm{MC} \\
\mathrm{C}<0.05 \% \mathrm{Nb}, \mathrm{V} \\
\mathrm{d}=0.007 \mathrm{~mm}\end{array}$ & $\begin{array}{c}R_{e}[\mathrm{MPa}] \\
R_{e} / R_{m} \\
A_{5} \quad[\%]\end{array}$ & $\begin{array}{c}390 \\
0.82 \\
38\end{array}$ & $\begin{array}{c}420 \\
0.82 \\
38\end{array}$ & $\begin{array}{c}440 \\
0.82 \\
38\end{array}$ & $\begin{array}{c}570 \\
0.9 \\
37\end{array}$ \\
\hline $\begin{array}{c}\mathrm{S} 460 \mathrm{MC} \\
\mathrm{C}<0.07 \% \mathrm{Nb} \\
\mathrm{d}=0.006 \mathrm{~mm}\end{array}$ & $\begin{array}{c}R_{e}[\mathrm{MPa}] \\
R_{e} / R_{m} \\
A_{5} \quad[\%]\end{array}$ & $\begin{array}{c}537 \\
0.86 \\
30\end{array}$ & $\begin{array}{c}550 \\
0.86 \\
30\end{array}$ & $\begin{array}{c}592 \\
0.86 \\
30\end{array}$ & $\begin{array}{c}700 \\
0.87 \\
29\end{array}$ \\
\hline $\begin{array}{c}\text { E500TS } \\
\mathrm{C}<0.08 \% \mathrm{Nb}, \mathrm{Ti} \\
\mathrm{d}=0.0056 \mathrm{~mm}\end{array}$ & $\begin{array}{c}R_{e}[\mathrm{MPa}] \\
R_{e} / R_{m} \\
A_{5} \quad[\%]\end{array}$ & $\begin{array}{c}540 \\
0.84 \\
39\end{array}$ & $\begin{array}{c}540 \\
0.84 \\
39\end{array}$ & $\begin{array}{l}550 \\
0.85 \\
39.5\end{array}$ & $\begin{array}{c}640 \\
0.94 \\
40\end{array}$ \\
\hline
\end{tabular}

malized steel has the highest sensitivity. Similarly, Fig. 3 documents the influence of $\dot{\varepsilon}$ on $\Delta R_{e}$ and $\Delta R_{m}$ of steels C4 and E500TS with different grain sizes. The grain boundaries are insuperable obstruc- tions to dislocation movement, therefore the finer grain the more obstructions, and the steel is less sensitive to the strain rate $\dot{\varepsilon}$. 
In terms of assessment of formability, the $R_{e} / R_{m}$ ratio is the most important criterion. Table 1 shows ratio $R_{e} / R_{m}$ of the tested steels at four testing conditions ( static $-10^{-3} \mathrm{~s}^{-1}$, two quasi-static $-2.5 \cdot 10^{-1}$ and $1 \mathrm{~s}^{-1}$ and dynamic $2.5 \cdot 10^{2} \mathrm{~s}^{-1}$ ) strain rates.

Based on the $R_{e} / R_{m}$ ratio at the static tensile test, the tested steels can be divided into three groups: steels with $R_{e}<300 \mathrm{MPa}$ and $R_{e} / R_{m}<0.7$, steels with $R_{e}>300 \mathrm{MPa}$ and $R_{e} / R_{m}>0.7$, and the third group is formed by steels with $R_{e}>500 \mathrm{MPa}$ and $R_{e} / R_{m}>0.8$.

The tests results shown in Tab.1, obtained on various steel grades, confirm that an increased strain rate results in an increased $R_{e} / R_{m}$ ratio and the intensity of this increase is a material function. The fewer obstructions to dislocation movement in a material, the more marked intensity of the influence of $\dot{\varepsilon}$. Fig. 4 shows an example how the grain size influences the $R_{e} / R_{m}$ ratio at various strain rates.

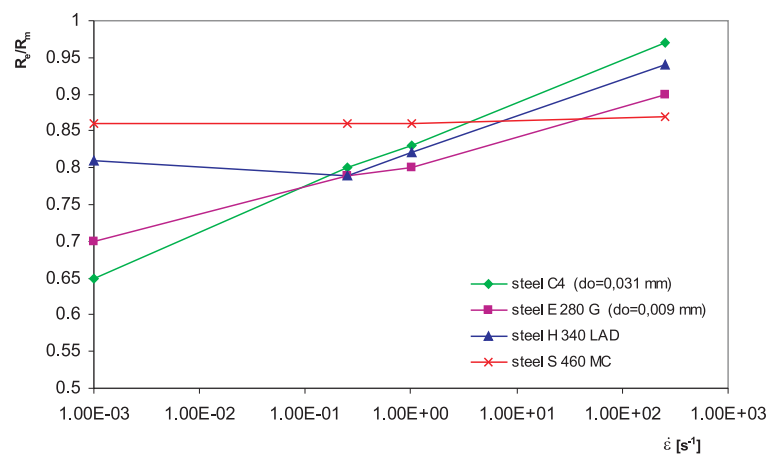

Fig. 4 Influence of the strain rate $\dot{\varepsilon}$ on $R_{e} / R_{m}$ for various steel grades.

The analysis of the results of strength properties $\left(R_{e}, R_{m}\right)$ obtained from tensile test shows that tested steels in strain rates ranging of $10^{-3}$ to $2.5 \cdot 10^{2} \mathrm{~s}^{-1}$ shows the $R_{e} / R_{m}$ ratio $<1$ and in terms of the macro-volume, up to this strain rate the plastic stability can be maintained up to the strain value corresponding to $R_{m}$. The critical value $\dot{\varepsilon}_{c r}$, at the ratio $R_{e} / R_{m}$ will equal 1 , is influenced by the internal material structure and it can generally be stated that the higher $R_{e}$, which is considered to be a macroscopic characteristic of the steel structure, the higher $\dot{\varepsilon}_{c r}$. As proven by the tests made on high-grade unalloyed steels with Re from 210 to $350 \mathrm{MPa}$ (E280G, H340LAD), $\dot{\varepsilon}_{c r}$ is in the interval from $10^{2}$ to $3.10^{2} \mathrm{~s}^{-1}$.

\section{Influence of the strain rate on the homogeneity of plastic deformation}

The elongation $(A)$ and the reduction of area $(Z)$ are the macroscopic characteristics of the plasticity of steel. Fig. 5 shows the graphic relationships $\dot{\varepsilon}-A$ and $\dot{\varepsilon}-Z$. Tab. 1 shows the values of these quantities at the characteristic strain rates. In terms of the influence of the strain rate in the interval from $10^{-3}$ to $2.5 \cdot 10^{2}$ $\mathrm{s}^{-1}$ on the above-mentioned characteristics, the tested steels can be classified under the group of steels where the elongation decreases with the growing strain rate, and under the group where the elon-

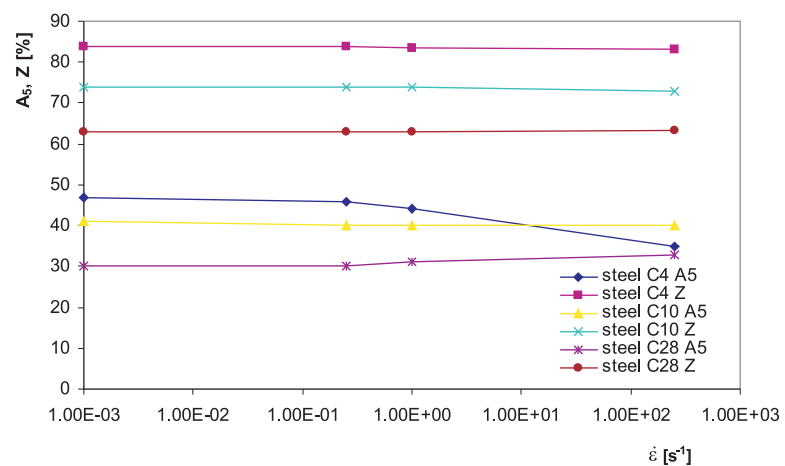

Fig. 5 Influence of the strain rate $\dot{\varepsilon}$ on the elongation $A_{5}$ and the reduction of area $Z$ of various tested steel grades

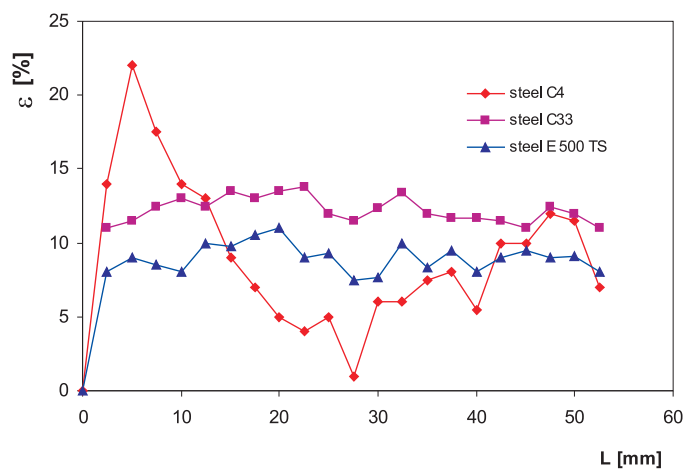

Fig. 6 Distribution of plastic deformation along the test bar at impact loading $10^{2} s-1$

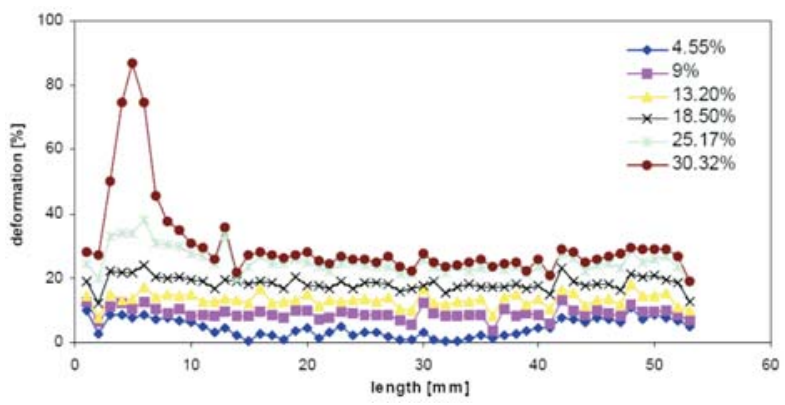

Fig. 7 Distribution of deformation long the test bar at various total strain degrees and impact loading $10^{2} \mathrm{~s}-1$ of steel $315 \mathrm{MC}$

gation does not change, or even grows. A decrease in the elongation with a growing $\dot{\varepsilon}$ is only shown by steels with $R_{e}<300 \mathrm{MPa}$ after exceeding $R_{e} / R_{m}>0.82$. Steels with a higher yield point 
maintain or even increase their elongation at $R_{e} / R_{m}>0.82$, too. The non-homogeneity of distribution of deformation along the test bar is influenced, besides the $R_{e} / R_{m}$ ratio, also by the $R_{m}-R_{e}$ difference. At a little difference, a very non-homogeneous distribution of deformation along the test bar, and hence a decreased elongation, can take place. This assumption is confirmed by Fig. 6 , which shows the distribution of deformation along the test bar at the strain rate of $10^{2} \mathrm{~s}^{-1}$ for steel $\mathrm{C} 4$, for which $R_{m}-R_{e}=10$ $\mathrm{MPa}$, steel $\mathrm{C} 33$, for which this difference is $160 \mathrm{MPa}$, and for steel E500TS, where this difference is $100 \mathrm{MPa}$. Fig. 7 documents the results of measuring the strain distribution along the test bars made of steel S315MC at individual degrees of total strain and dynamic loading. The results of the influence of the strain rate on the criteria of macro non-homogeneity $\mathrm{M}$ of the tested steels are presented in Fig. 9. The results show that the non-homogenous strain distribution along the test bar increases with an increased strain degree. The influence of the strain rate on the strain distribution along the test bar depends on the properties of steel. If $R_{e} / R_{m}$ approaches to 1 at a given strain rate, then the non-homo-

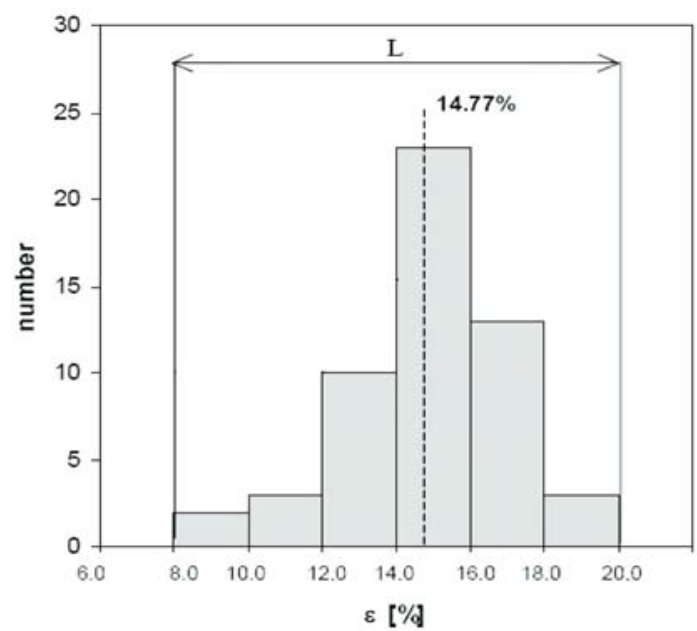

Fig. 8 Histogram of strain distribution at the mean strain $\varepsilon=14.77 \%$ of steel $315 \mathrm{MC}$ at the strain rate of $10^{-3} \mathrm{~s}^{-1}$

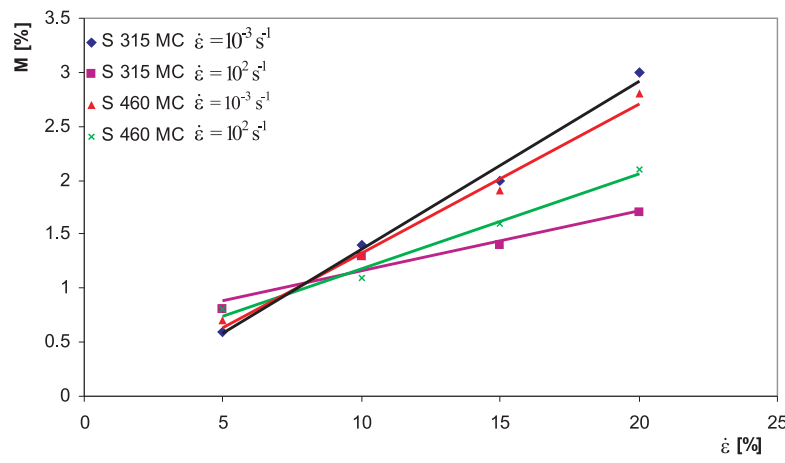

Fig. 9 Relationship between the mean macro non-homogeneity $M$ and the mean strain degree in a micro-area $(1 \times 0.5 \mathrm{~mm}) \varepsilon$ at the strain rates of $10^{-3}$ and $10^{2} \mathrm{~s}^{-1}$ of selected steels geneity of strain distribution along the test bar significantly increases (see Fig. 6, steel C4). If $R_{e} / R_{m}<1(0.82$ to 0.9$)$, the strain rate favourably influences the strain distribution along the test bar (Fig. 6 and Fig. 9).

The results of the influence of the strain rate on the criteria for micro non-homogeneity of $\mathrm{M}$ and $\mathrm{L}$ are presented in Fig. 10 and Fig. 11. L is the range of the statistic population (Fig. 8). The results confirms that the micro non-homogeneity increases with an increasing strain degree.

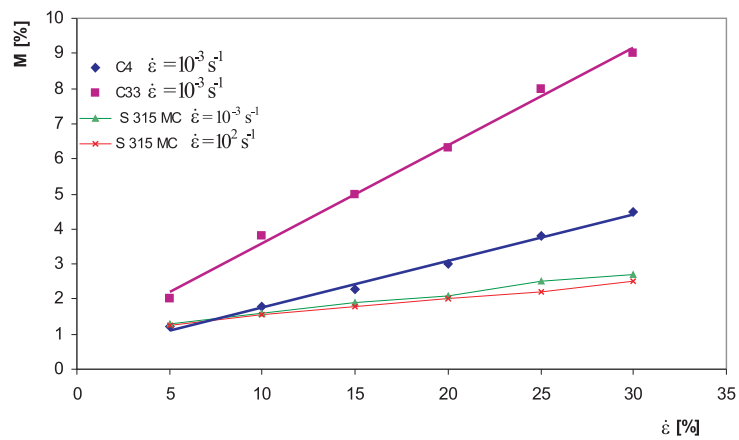

Fig. 10 Relationship between the mean micro non-homogeneity $M$ and the mean strain degree in a micro-area $(1 \times 0.5 \mathrm{~mm}) \varepsilon$ at the strain rates of $10^{-3}$ and $10^{2} \mathrm{~s}^{-1}$ of selected steels

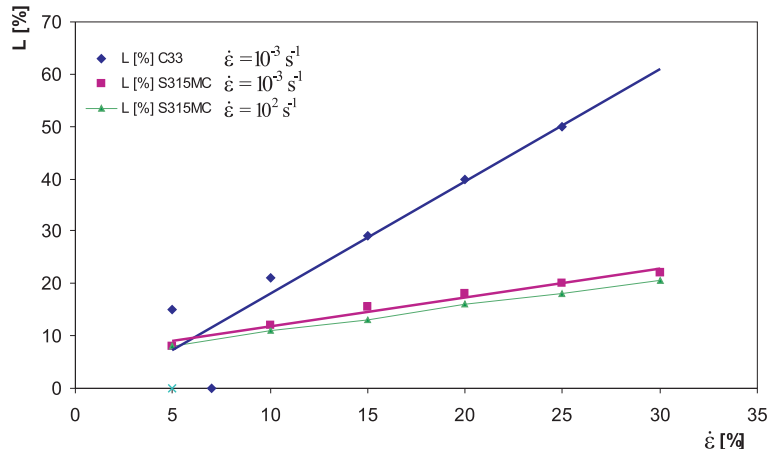

Fig. 11 Relationship between the range of the statistic population $L$ and the mean strain degree in a micro-area $\varepsilon$ at the strain rates of $10^{-3}$ and $10^{2} s^{-1}$

The results of evaluation of non-homogeneity of plastic deformation show that in the interval of these strain rates from $10^{-3}$ to $10^{2} \mathrm{~s}^{-1}$ the non-homogeneity slightly decreases or does not change with an increasing strain rate of the tested steels. This means that forming these steels at higher rates practically does not influence the properties of these products.

The intensity of increase in the non-homogeneity of plastic deformation with an increasing strain degree is a function of the structure, as shown by the results. The degree of non-homogeneity of the steel $\mathrm{C} 33$ with the ferrite and pearlite structure is as many as three-times higher than that of steel $\mathrm{C} 4$ with the ferrite 
structure. It results from Fig. 9-11 that these relationships can be described using the formulae $M=a+k_{1} \cdot \varepsilon, L=b+k_{2} \cdot \varepsilon\left(k_{1}\right.$ and $k_{2}$ are material constants). Here it also applies that the less obstructions to dislocation movement in steel, the more non-homogeneous its deformation process, but this deformation process is practically not influenced by the increase in the strain rate.

\section{Conclusions}

The aim of the paper was to assess the influence of the strain rate in the interval from $10^{-3}$ to $2.5 \cdot 10^{2} \mathrm{~s}^{-1}$ on the mechanical properties, with regard to the plasticity of un-alloyed high-grade steels with the yield point from 210 to $550 \mathrm{MPa}$. Based on the analysis of experimental results obtained from a long time and literature knowledge, the following can be stated:

- The resistance of materials to plastic deformation increases with an increasing strain rate, which increases the strength properties of the tested steels and the yield point to tensile strength ratio $R_{e} / R_{m}$.
- The intensity of increase in $R_{e} / R_{m}$ with an increasing strain rate is a function of the internal material microstructure. $R_{e}$. The intensity of increase in $R_{e} / R_{m}$ with an increasing strain rate is the highest at steels with $R_{e}<300 \mathrm{MPa}$, lower at steels with $R_{e}<500 \mathrm{MPa}$, and slight at steels with $R_{e}>500 \mathrm{MPa}$

- The influence of the strain rate on the plasticity (elongation and reduction of area) values is based on $R_{e} / R_{m}$. Only steels with $R_{e}$ $<300 \mathrm{MPa}$ show a decreased elongation in the observed strain rate interval, from the strain rate where $R_{e} / R_{m}>0.82$. Steels with a higher yield point maintain or increase their elongation.

- The non-homogeneity of plastic deformation increases with an increasing strain degree. The intensity of macro and micro nonhomogeneity is a function of the internal material microstructure. An increasing strain rate slightly decreases the micro non-homogeneity of plastic deformation.

Acknowledgemet: This work has been supported by APVV Agency under No. APVV-0326-07

\section{References}

[1] PUSKAR, A.: Medzne stavy materialov a sucasti [Limit States of Materials and Components], Veda Bratislava, 1989 (in Slovak).

[2] MICHEL, J.: Materialove inzinierstvo [Materials Engineering], 3/1996, p. 22 (in Slovak).

[3] BURSAK, M., MICHEL, J., STABA, J.: Materialove inzinierstvo [Materials Engineering], 14/2007, 3, 195 (in Slovak).

[4] ELFMARK, J.: Plasticita kovu, [Metal Plasticity], VSB Ostrava, 1984 (in Czech).

[5] MICHEL, J., MAMUZIC, I., BURSAK, M.: Metalurgija [Metallurgy], 35/1996, 2, p. 69 (in English).

[6] MICHEL, J., MIHALIKOVA, M.: Vplyv vybranych faktorov na vlastnosti konstrukcnych oceli [Effect of Selected Factors on the Properties of Structural Steels], Letna skola unavy : Zilina : Oscadnica, 2008 (in Slovak).

[7] MICHEL, J., CIZMAROVA, E., ORUZINSKA, S.: Kovove materialy [Metallic Materials], 37/1999, 3, p. 191 (in Slovak).

[8] CIZMAROVA, E., MICHEL, J.: Acta Metallurgica Slovaca, 9/2003, p. 90. (in English).

[9] BURSAK, M., MAMUZIC, I.: Metalurgija [Metallurgy], 46/2007, 1, p. 37 (in English).

[10] JANOVEC, J., ZIEGELHEIM, J.: Rust uzitnych vlastnosti u tenkych automobilovych plechu [Enhancement of Utility Properties on Thin Automotive Sheets], In: Technologie '99, STU Bratislava, 1999, p. 319 (in Czech).

[11] ZHU YUNTIAN, LONGDON TERENCE: In: Materials Science and Engineering, A409 (205), 234

[12] NIECHAJIVICZ,A., TOBOTA, A.: In Arcivives of Civil Mechanical Engineering, Vol. VIII., No.2, (2008), 129

[13] MISHRA, A. at all.: In: Acta Materialia 56, (2008), 2770. 